\title{
Managing the Turf of An Urban Golf Course: Energy Consumption and Greenhouse Gas Emission
}

Lai Fern Ow ${ }^{1,}{ }^{*}$, Eugenie Chan ${ }^{2}$

1. Centre for Urban Greenery and Ecology, National Parks Board, 1E Cluny Road, 259601, Singapore; E-Mail: genevieve ow@nparks.gov.sg

2. Lifelong learning, Continuing Education Training Academy, Ngee Ann Polytechnic, 535 Clementi Road, 599489, Singapore; E-Mail: Eugenie_CHAN@np.edu.sg

* Correspondence: Lai Fern Ow; E-Mail: genevieve_ow@nparks.gov.sg

Academic Editor: Zed Rengel

Adv Environ Eng Res

2022, volume 3, issue 1

doi:10.21926/aeer.2201003
Received: October 21, 2021

Accepted: January 12, 2022

Published: January 24, 2022

\begin{abstract}
This study investigated energy consumption and greenhouse gas (GHG) emission across various playing surfaces (e.g., greens, tees, fairways, and roughs) in an urban parkland golf course. The turfs of golf courses require frequent maintenance to ensure high aesthetic and play quality. Maintenance includes aeration, mowing, irrigation, and fertilization. The annual energy-based carbon footprint was found to be the highest for fairways, followed by greens, tees, and roughs. However, $\mathrm{CO}_{2}$ exchange in the grass was found to be the highest for roughs, followed by fairways and greens. The higher energy consumption in fairways might be attributed to intensive maintenance and its larger surface area. Higher values of $\mathrm{CO}_{2}$ exchange for roughs might be attributed to biomass as these areas of the course were mowed lesser than the other areas. The maintenance activities such as mowing, hollow tining, and irrigation were the most energy-demanding, while GHG emissions occurred primarily due to mowing, fertilizer application, grass clippings, and $\mathrm{CO}_{2}$ turfgrass exchange. Therefore, the strategies to minimize energy consumption and GHG emissions in golf courses include the use of electricpowered equipment and a reduction in the frequency of energy-demanding maintenance activities, including those that emit large quantities of $\mathrm{CO}_{2}$. Planting more shrubs and trees along the golf course might offset the emissions and thus, turn golf courses into a carbon sink
\end{abstract}

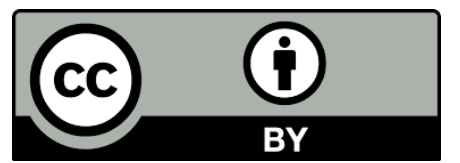

(C) 2022 by the author. This is an open access article distributed under the conditions of the Creative Commons by Attribution License, which permits unrestricted use, distribution, and reproduction in any medium or format, provided the original work is correctly cited. 
for GHG emissions. However, sustaining a low carbon footprint is not always simple for golf courses as the expectations of golfers for aesthetics and play quality might need to be prioritized against environmental concerns.

\section{Keywords}

Energy use; golf course; greenhouse gas emissions; shrubs \& trees; turf maintenance

\section{Introduction}

Climate change is a global concern, and attempts are being made to mitigate it. Many countries have pledged to reduce greenhouse gas (GHG) emissions under the Paris Agreement on climate change, and several countries have committed to minimizing GHG emissions between 2030 and 2050. Reducing GHG emissions requires finding new renewable energy supplies, and achieving such ambitious targets requires the concerted efforts of governments, businesses, households, and individuals. Reversing the effects of climate change requires the reduction of carbon emissions during power generation, development and demonstration of innovative low carbon technologies, and improving the efficiency of energy consumption. Such efforts are critical as the current state of the climate, as per the recent intergovernmental panel on climate change (IPCC) report in 2021 [1], indicated an increase in GHG concentrations, which reached annual averages of $410 \mathrm{ppm}$ for $\mathrm{CO}_{2}$, $1,866 \mathrm{ppb}$ for $\mathrm{CH}_{4}$, and $332 \mathrm{ppb}$ for $\mathrm{N}_{2} \mathrm{O}$ in 2019. The last four decades have been progressively warmer than any decade that preceded it. For example, the global surface temperature was $1.09{ }^{\circ} \mathrm{C}$ higher in 2011-2020 than 1850-1900, and most of these changes were caused by anthropogenic activities. Human-induced climate change is causing weather and climate extremes (e.g., heat waves, heavy precipitation, droughts, etc.) across the globe. For the first time, the report also sought to project and establish scenarios that cover the future possibilities for the development of anthropogenic drivers in the short-term (by 2040), mid-term (by 2060), and long-term (by 2100) scale to predict future changes in global surface temperatures, ocean warming, and sea levels [1].

Though golf courses have large areas of greenery, they are key emitters of $\mathrm{CO}_{2}$ generated primarily from frequent maintenance activities. Previous reports have shown that managed turf surfaces contribute to soil carbon (C) sequestration [2,3]. Here, we investigated the golf courses in Singapore as an example. Occupying $721.5 \mathrm{~km}^{2}$, the island nation of Singapore has 14 private golf courses and three public courses, which cover approximately 1,500 ha or about $2 \%$ of the total land area (www.todayonline.com) [4]. Playing golf can keep a person healthy; hence, a part of the land is reserved, where the greenery is manicured, and the greenery from the turf, shrubs, trees, and water features have been shown to improve biodiversity [5]. However, as the population grows further, the demand for the use of land for agriculture, parks, and real estate will increase (www.greenbiz.com) [6], and sustainable maintenance practices will gain momentum. Regarding the land used as golf courses, environmentalists dislike the use of non-native grasses, as they eliminate or interrupt natural habitats. Additionally, fertilizers and pesticides are used frequently, mowers and golf carts have to be filled with petroleum, and these factors contribute to habitat disruption and the interruption of natural waterways (https://blueandgreentomorrow.com) [7]. 
Besides chemicals and petroleum, golf course maintenance also requires plenty of water. Thus, the frequent maintenance of golf courses adversely affects the environment and increases GHG emissions (e.g., nitrous oxide $\left.\left(\mathrm{N}_{2} \mathrm{O}\right) \& \mathrm{CO}_{2}[8,9]\right)$. Furthermore, the frequency and intensity of golf course maintenance are considerably more intense than the maintenance of parks and gardens.

Frequently mowing, fertilizing, and aerating a golf course is not only energy-intensive but also increases GHG emissions both within and outside the golf course. For example, these processes influence the external environment by the production of mineral fertilizers and the use of fuel for machinery and transportation [10]. Previous reports have mostly focused on GHG emissions in public and private lawns [11-13], while only a few have examined the impacts on golf courses, and even lesser published information is available on golf courses in urban areas.

A previous report by Bartlett and James [14] used a modeling approach to examine the sourcesink relationship of a golf course and concluded that the areas managed the most are a net source of carbon emissions. The mature trees in the course that were accounted for within their model had a positive and significant impact on the net carbon balance, thus indicating the importance of planting trees and shrubs within the course to offset the emissions.

Besides the concerns regarding emissions, turf maintenance across various courses differ based on green management standards, course design, and microclimatic conditions. Additionally, the different playing surfaces of a golf course (e.g., greens, tees, fairways, and roughs) receive different intensities of management. Advancements and innovations in turfgrass strains and drainage design are some examples of efforts made to combat climate change. For example, modern turfgrass strains are more tolerant to heat and drought [15], and these were developed to conserve water, as they require less irrigation. Additionally, computerized irrigation systems have been installed, and they can determine the optimum quantity of water required in different locations of a course, thus using water efficiently [16]. Computerized systems can optimize the activity of water pumps, which minimizes energy consumption. Likewise, modern mowers and machines used for aerification and other maintenance activities are more efficient and thus, save time. This reduces the usage of resources and lowers GHG emissions.

Limited knowledge is available on efficient and sustainable turf management practices, and limited research has been conducted on golf courses. Therefore, more quantitative analysis of energy utilization and GHG emissions from the different areas of a golf course (e.g., tees, greens, fairways, and roughs) is required, given that these areas receive substantially different levels of care and maintenance. Such studies are important as golf courses play a similar role to parks, lawns, and open public green spaces in providing and supporting recreational and physical activities. Therefore, this study was aimed to determine the annual energy consumption and GHG emissions from an urban golf course and investigate the relative contributions of the various playing surfaces such as tees, greens, fairways, and roughs. Additionally, this study sought to understand energy consumption and GHG emissions for the various maintenance activities that are frequently performed on a golf course (e.g., mowing, irrigation, fertilization, etc.) and, by doing so, determine more efficient management practices to limit energy usage and the associated GHG emissions. This can encourage more sustainable practices in golf courses. 


\section{Methods}

Life cycle analysis (LCA) was performed to understand energy utilization and GHG emissions associated with turf management on the golf course over one year. LCA accounted for both direct and indirect environmental pressures because energy utilization and GHG emissions are not only associated with the maintenance activities on the golf course but are also indirectly enhanced by environmental factors associated with the production of mineral fertilizers, machinery, fuel, and transport of sand, for example, used for topdressing. Energy utilization and GHG emissions for turf management were presented in the form of $t-\mathrm{CO}_{2}$ and $\mathrm{CO}_{2}$ flux $\left(\mathrm{mg} \mathrm{CO}_{2}-\mathrm{C} \mathrm{m}^{-2} \mathrm{hr}^{-1}\right)$, respectively, as per the IPCC reports. Information on management practices was obtained through interviews with course superintendents and horticulture ground staff. A brief description of various maintenance activities that were conducted frequently on the course is described in this section of the paper.

\subsection{Course Information}

The land area of the various playing surfaces in the golf course is detailed in Table 1 . We investigated an urban parkland course located in the north of Singapore $\left(1.2521^{\circ} \mathrm{N}, 103.8198^{\circ} \mathrm{E}\right)$. The course had nine holes and was built in 1993. A reservoir and thick rows of trees surrounded the course. The holes in the course were situated in and around sand bunkers, water features, and roughs that had medium-to-large trees and shrubs (Figure 1). Maintenance regimes were generally similar for the entire course, with few differences between the various playing surfaces (e.g., greens, tees, fairways, etc.) to ensure optimal play conditions.

Table 1 The area (in $\mathrm{km}^{2}$ ) of the various playing surfaces in the golf course (Source: Course Superintendent) and \% energy CF and GHG emissions for various playing surfaces across the course.

\begin{tabular}{llll}
\hline playing surfaces & $\begin{array}{l}\text { Size } \\
\left(\mathbf{k m}^{\mathbf{2}}\right)\end{array}$ & GHG emissions (\%) & $\begin{array}{l}\text { Energy use } \\
(\mathbf{\%})\end{array}$ \\
\hline Greens & 0.025 & 26 & 28 \\
Tees & 0.022 & 21 & 25 \\
Fairways & 0.28 & 22 & 33 \\
Roughs & 0.4 & 31 & 14 \\
& Total:0.727 & & \\
\hline
\end{tabular}



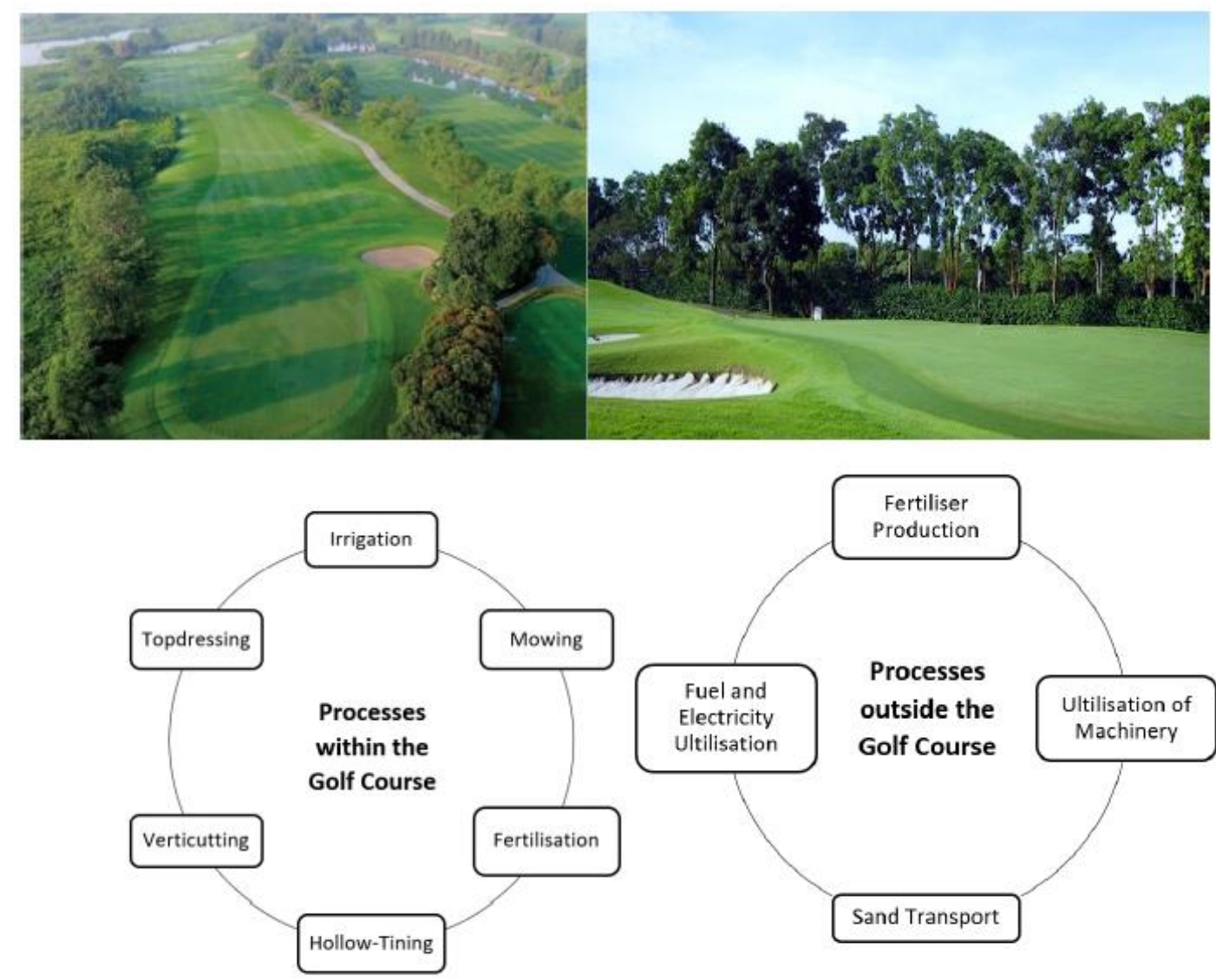

Figure 1 An aerial image of the golf course (top left) and a sand trap within the course (top right). (Bottom) The processes within and beyond the course affect energy usage and GHG emissions.

\subsection{Maintenance Regimes - Fertilization, Chemical Application, \& Irrigation}

Tees and greens were fertilized manually, while fairways were fertilized mechanically every three months. The roughs, on the other hand, were not fertilized. The data used in this study was from 2018 and was considered to accurately represent the scenario in other years. Insecticides, fungicides, and herbicides were applied as and when required, which was decided by the course superintendent and depended on the health and condition of the turfgrass.

Generally, the turf was irrigated twice a day using water from a pond within the course, and water was transported through an underground network of pipes to various areas of the course. The irrigation frequency varied and depended on the level and intensity of rainfall experienced at the site monitored by the meteorological stations. The average number of days of rain was 16 and the average precipitation at the site was $142.4 \mathrm{~mm}$ per month. The 24-hour average temperature was $28.7^{\circ} \mathrm{C}$. All areas of the course were irrigated using in-ground sprinklers except for the roughs, which were not irrigated. The estimated volume of water applied to each surface of the course annually is presented in Table 2, with an average of 2,226 $\mathrm{L} \mathrm{ha}^{-1}$ across the various playing surfaces. Irrigation was automated and based on a time-sensitive system. The details on the application of fertilizers and chemicals are also presented in Table 2. 
Table 2 The estimate of water, fertilizer ( $N, P$, and $K$ ), sand, and pesticide used in the different playing surfaces across the course annually.

\begin{tabular}{lllllll}
\hline $\begin{array}{l}\text { Playing } \\
\text { surfaces }\end{array}$ & $\mathbf{N}(\mathbf{k g})$ & $\mathbf{P}(\mathbf{k g})$ & $\mathbf{K}(\mathbf{k g})$ & $\begin{array}{l}\text { Pesticide } \\
\mathbf{( k g )}\end{array}$ & Sand $(\mathbf{t})$ & $\begin{array}{l}\text { Irrigation } \\
\left.\mathbf{( L ~ h a}^{\mathbf{- 1}}\right)\end{array}$ \\
\hline Greens & 385 & 227 & 229 & 201 & 441 & 2116 \\
Tees & 342 & 213 & 217 & 145 & 255 & 2027 \\
Fairways & 211 & 166 & 171 & 110 & 189 & 2535 \\
\hline
\end{tabular}

\subsection{Maintenance Regimes - Aerification, Mowing, \& Topdressing}

Aerification was conducted with walk-behind aeration equipment for greens and tees, while a tractor-mounted system was used on fairways once a month. Hollow tining was performed for greens, tees, and fairways at variable frequencies depending on the condition of the turf, as determined by the ground staff. Verticutting was exclusively performed for greens.

A ride-on rotary mower was used for mowing. Greens were mowed daily and tees were mowed five to six times a week. Fairways were mowed four times a week, while roughs were mowed twice a week. Clippings were removed from greens and tees and applied across roughs, while clippings from fairways and roughs were left to degrade. Topdressing was applied to greens, tees, and fairways only and the sand for topdressing was transported $32 \mathrm{~km}$ from the source to the course. The frequencies of activities such as aerification, mowing, and topdressing are presented in Table 3.

Table 3 The annual maintenance cycles performed on different playing surfaces of the golf course, the associated fuel utilization $\left(\mathrm{L} \mathrm{km}^{-2}\right.$ event $\left.{ }^{-1}\right)$, and energy consumption ( $\mathrm{t}$ $\mathrm{CO}_{2}$ year $^{-1}$ ) for various maintenance processes.

\begin{tabular}{|c|c|c|c|c|c|c|c|c|c|}
\hline & \multicolumn{3}{|c|}{$\begin{array}{l}\text { Frequency of Annual } \\
\text { Maintenance }\end{array}$} & \multicolumn{3}{|c|}{$\begin{array}{l}\text { Fuel Consumption }\left(\mathrm{L} \mathrm{km}^{-2}\right. \\
\left.\text { year }^{-1}\right)\end{array}$} & \multicolumn{3}{|c|}{$\begin{array}{l}\text { Energy-based carbon } \\
\text { footprint } \mathrm{CF}_{e}\left(\mathrm{t}-\mathrm{CO}_{2} \text { year }{ }^{-1}\right)\end{array}$} \\
\hline & Green & Tee & Fairway & Green & Tee & Fairway & Green & Tee & Fairway \\
\hline Mowing & 365 & 260 & 208 & 33.5 & 33.3 & 82.1 & 3380 & 2890 & 2210 \\
\hline Hollow Tining & 52 & 24 & 12 & 19.2 & 14 & 32.5 & 1850 & 1630 & 1310 \\
\hline Verticutting & 12 & 0 & 0 & 12.4 & 2.5 & 4.9 & 1910 & 0 & 0 \\
\hline Topdressing & 12 & 6 & 3 & 29.8 & 19.2 & 56.1 & 1456 & 1137 & 1550 \\
\hline Irrigation & 730 & 730 & 730 & 31.3 & 27 & 43.7 & 1230 & 1250 & 1470 \\
\hline Fertilization & 52 & 52 & 4 & 2.1 & 2.2 & 89.8 & 0 & 0 & 2250 \\
\hline
\end{tabular}

\subsection{Fuel Utilization}

An average of $535 \mathrm{~L}$ of hydraulic fluids is used annually for mechanical maintenance (the assumption was made that petrol and diesel had similar GHG emissions) for various processes such as aerification, mowing, topdressing, etc. to maintain the greens, tees, and fairways (Table 3 ), and these estimates were based on the utilization for the 12 months of 2018. Any discrepancies in Table 3 between the various maintenance processes in fuel consumption are probably due to the different mechanical equipment used that had variable fuel consumption rates. 
We also accounted for the external inputs that contributed to energy consumption during the year of assessment (Figure 1, bottom images). These factors included the production of fertilizer, utilization of equipment, and transportation of sand. For example, the average diesel used for transporting sand was set at $0.6 \mathrm{~L} \mathrm{~km}^{-1}$ assuming a dump truck was used and accounting for an empty return trip. We did not include information on the production of insecticides, herbicides, and fungicides as the course superintendent had informed (through interviews) that the application of these chemicals was avoided unless necessary for environmental reasons. Therefore, the rate of applications was less than $6 \%$ of the overall GHG and energy emissions.

\section{$2.5 \mathrm{CO}_{2}$ Emissions within and outside the Golf Course}

Sometimes, it can be difficult to collect data for GHG emissions resulting from the transport of sand, production of fertilizers, and maintenance and use of machinery, which account for external emissions. Therefore, a rough estimate was made by assuming that the energy consumed and GHG emitted for manufacturing, maintaining, and repairing machinery comprised $17 \%$ of the total energy consumed and GHG emitted for all turf operations. This estimate was based on the reports published by Tidåker et al. [10, 17]. These estimates were made for the conditions in Sweden; however, since there were no data available for Asia, they were used here; efforts are being made to gather region-specific data. Electricity consumption for irrigation was estimated to be $1.8 \mathrm{kWh}$ $\mathrm{m}^{-3}$ by the course superintendent. A factor of 2.3 was used while estimating the conversion of electricity to primary energy coupled with a $65 \%$ rate of transformation efficiency, following the study by Tidåker et al. $[10,17]$. To estimate $\mathrm{CO}_{2}$ emissions from machines such as lawnmowers and mechanical tractors used for fertilization, aerification, and topdressing, we followed the methods used in the studies by Horn et al. [18] and Lerman \& Contosta [19]. In this study, total $\mathrm{CO}_{2}$ emission from each playing surface (CE) was determined by multiplying the usage rate $(u)$ with the fuel consumption rate of the machine (f) and the carbon emission factor of fuel $(x)$. The product of these three was divided by the total area of the playing surface (a), and the results were converted from $\mathrm{g} \mathrm{CO}_{2}$ to $\mathrm{g} \mathrm{CO}_{2}-\mathrm{C}$ using their molecular weights $(\mathrm{m})$, as shown in equation (1).

$$
\mathrm{CE}\left(\frac{g \mathrm{CO}_{2}-C}{m^{2} / \text { time }}\right)=\frac{u * f * x}{a} * m
$$

For each playing surface, we determined the usage rate $(u)$ in hours over three months. The fuel consumption rate (f) was estimated to be $1.5 \mathrm{~L}$ of fuel per hour, assuming it was a $5.23 \mathrm{~kW}$ mower. The emissions factor ( $\mathrm{x}$ ) was set at $2.82 \mathrm{~kg} \mathrm{CO}_{2}$ per L of fuel [20], which was converted to $\mathrm{g}$ of $\mathrm{CO}_{2}$ per $\mathrm{L}$. The area of the playing surface (a) was calculated in $\mathrm{m}^{2}$, and this equation was similar to the one used by Lerman \& Contosta [19]. We converted the $\mathrm{CE}$ from $\mathrm{g} \mathrm{CO}_{2} \mathrm{~m}^{-2}$ time $^{-1}$ to $\mathrm{g} \mathrm{CO}_{2}-\mathrm{C} \mathrm{m}^{-2}$ time ${ }^{-1}$ assuming the molecular weight of $C$ to be $12.012 \mathrm{~g} \mathrm{~mol}^{-1}$ relative to the molecular weight of $\mathrm{CO}_{2}\left(44.010 \mathrm{~g} \mathrm{~mol}^{-1}\right)(\mathrm{m})$.

The energy-based carbon footprint $\left(\mathrm{t}-\mathrm{CO}_{2}\right)$ was determined using equation (2).

$$
C F_{e}=\sum_{i}\left(E * G C V * E F_{e}\right)
$$


Here, $\mathrm{CF}_{e}$ indicates the energy-based carbon footprint, $E$ indicates energy consumption, GCV indicates the calorific value $\left(\mathrm{MJ} \mathrm{m}^{-3}\right)$, and $\mathrm{EF}_{e}$ indicates the energy-based $\mathrm{CO}_{2}$ emission factor $\left(\mathrm{t}-\mathrm{CO}_{2}\right.$ $\left.\mathrm{MJ}^{-1}\right)$.

\section{6 $\mathrm{CO}_{2}$ Emissions from Grass Clippings and Fertilization}

The clippings obtained by mowing the greens and tees were mostly distributed across the sides of fairways and left predominantly on roughs. The clippings obtained by mowing fairways and roughs also were spread across roughs and left to degrade. Since $\mathrm{N}_{2} \mathrm{O}$ emission across the course was highly variable that could not be measured, the variability in $\mathrm{N}_{2} \mathrm{O}$ was accounted for in the simulation analysis. However, indirect emissions of $\mathrm{N}_{2} \mathrm{O}$ (e.g., $\mathrm{N}$ losses through leaching or volatilization) were excluded from the analysis. The direct emissions estimated in this study were based on the refinement (2019) to the IPCC guidelines (2006) for national greenhouse gas inventories, where $1.5 \%$ of the total $\mathrm{N}$ used as fertilizers was considered to be the emission factor for grass clippings in the simulation analysis [21]. Likewise, fertilizers comprised of nitrate and urea ammonium were accounted for in the analysis since the fertilizers applied to the course comprised a mixture of ammonium, nitrate, and urea that contributed to $\mathrm{CO}_{2}$ emissions. Data on energy consumption and GHG emissions for the production of fertilizers were taken from estimates made in Washington, USA (www.tfi.org/our-industry/state-of-industry/environment-energy) [22] and the United Kingdom (www.farmcarbontoolkit.org.uk/toolkit/fertiliser-production) [23], respectively, for the simulation analysis as there was no data available for Asia. $\mathrm{CO}_{2}$ flux was quantified using a static chamber technique detailed in Lerman \& Contosta [19]. Measurements were made in three locations across the various playing surfaces using a sealed chamber and a lid placed over a collar for collecting the headspace samples. Three chambers $\left(0.02 \mathrm{~m}^{3}\right)$ were placed on the surface of the clippings and sites where fertilizers had been applied (for fertilizers, measurements were observed after 24-48 h). To avoid differences in pressure between the chamber and the ambient air, vent tubes were installed. Headspace samples were obtained at intervals of 5, 10, and $15 \mathrm{~min}$. The samples were then injected into He-flushed $35 \mathrm{~mL}$ vials. Ambient samples were also collected to determine $\mathrm{CO}_{2}$ concentrations at the start of the 15-min incubation. Air and soil temperatures were measured at the same time with a digital soil thermometer and moisture probe (HydraProbe II Soil Moisture \& Soil Temperature Probe), and the height of the clippings was measured to correct for chamber volume. The $\mathrm{CO}_{2}$ concentration was determined using a Hansatech EGM 5 portable $\mathrm{CO}_{2}$ infrared gas analyzer (Hansatech Instruments Ltd., Norfolk, United Kingdom). The exchange of $\mathrm{CO}_{2}$ involving the turfgrass across the various playing surfaces was measured using the same method and equipment.

\section{Results}

Greens had the highest requirement for fertilizer, pesticide, and sand application (Table 2). Fairways had the greatest requirement for irrigation. The frequency of mowing, hollow tining, verticutting, and topdressing was also higher for greens than for any other playing surface (Table 3). Mowing and irrigation were the most intensively performed maintenance activities and consumed the most amount of fuel. Although the frequency of irrigation was the highest, the energy consumption was not significantly greater $(P=0.704)$ than that for hollow tining, which was conducted $90 \%$ less often (on an annual basis) on the course (Table 3 ). 


\subsection{Energy and Resource Utilization}

The annual energy footprint was highest for fairways, followed by greens and tees; however, the difference in energy consumption between fairways and greens was $2.5 \%$ (Table 3 ). The annual energy footprint for tees was significantly lower (33\%) than that for fairways and greens. The roughs consumed the least unit of energy, and thus, the data are not presented. Moreover, roughs consumed less than $15 \%$ of the annual energy footprint (across the entire course). Mowing was the most energy-demanding process across greens, tees, and fairways (Table 3 ). The annual energy footprint for irrigation across greens, tees, and fairways was approximately $54 \%$ lower than that for mowing, although the frequency of irrigation was 50\% higher. The annual energy footprint for hollow tining was $17.5 \%$ higher than that for irrigation, although the frequency of irrigation was $90 \%$ higher than hollow tining (Table 3).

The golf course was primarily covered by roughs $\left(0.4 \mathrm{~km}^{2}\right)$, followed by fairways $\left(0.28 \mathrm{~km}^{2}\right)$, greens, and tees (Table 1). To visualize energy utilization across the entire course, values (in percentage) were presented and separated into the various playing surfaces (Table 1). This was done to facilitate inferences on which maintenance activities coupled with the playing surfaces contributed to higher utilization of energy. Despite a small land area of $0.025 \mathrm{~km}^{2}$ (greens), the total energy consumed by greens was $28 \%$ of the total energy consumed (Table 1 ). This was only $5 \%$ lesser than the energy consumed by fairways, which had $94 \%$ more land area than greens. Given the high frequency of irrigation, the annual water consumption across greens, tees, and fairways was considerably high (Table 2). The volume of water used for irrigation of fairways was significantly greater $(P=0.04)$, and this might be due to the size of the fairways (Table 1$)$. Additionally, the application of pesticides and potassium and phosphorus fertilizers showed no significant differences $(P=0.643)$ across an annual cycle. The level of nitrogen fertilizers was significantly higher $(P=0.05)$ than those of potassium and phosphorus across greens, tees, and fairways. Overall, the application of sand, chemicals, and fertilizers was the highest for greens, except for irrigation, although the area occupied by greens was negligible relative to that occupied by the other playing areas (Table 1).

\subsection{GHG Emissions and $\mathrm{CO}_{2}$ Flux}

GHG emissions for maintenance were primarily contributed by mowing, fertilization, and the grass clippings left to degrade on roughs (Figure 2A), while emissions from the turfgrass across the various playing surfaces were about 59\% lower (Figure $2 \mathrm{~B}$ ). The transportation of sand and the production of mineral fertilizers also contributed significantly to GHG emissions. The results showed that GHG emissions in these maintenance processes and due to the exchange of grass were the highest for roughs, although they were maintained to a much lesser extent (Table 1 \& Figure 2A \& $2 \mathrm{~B})$. For example, the roughs did not receive any fertilizer, and mowing was performed considerably less frequently than the other playing surfaces. However, the $\mathrm{CO}_{2}$ flux of the grass in the roughs was significantly higher $(P=0.02)$ and 45 to $56 \%$ lower for the grass in fairways, greens, and tees (Figure 2B). Similarly, mowing exhibited significantly higher $(P=0.04) \mathrm{CO}_{2}$ flux than fertilizer application and grass clippings (Figure 2A). A smaller difference (13\%) was observed in the $\mathrm{CO}_{2}$ flux between fertilizer application and grass clippings. Greens and tees received fertilizers regularly, and hence, they had high GHG emissions that differed by 5 to $10 \%$ compared to roughs, although the surface area of tees and greens was lesser than that of roughs (Table 1). Despite the high frequency of irrigation, the $\mathrm{CO}_{2}$ flux due to this process was relatively low. Although fairways covered a large area 
and followed a high-maintenance regime, they did not contribute greatly to GHG emissions; only a $1 \%$ difference was observed between the GHG emissions of fairways and tees (Table 1).
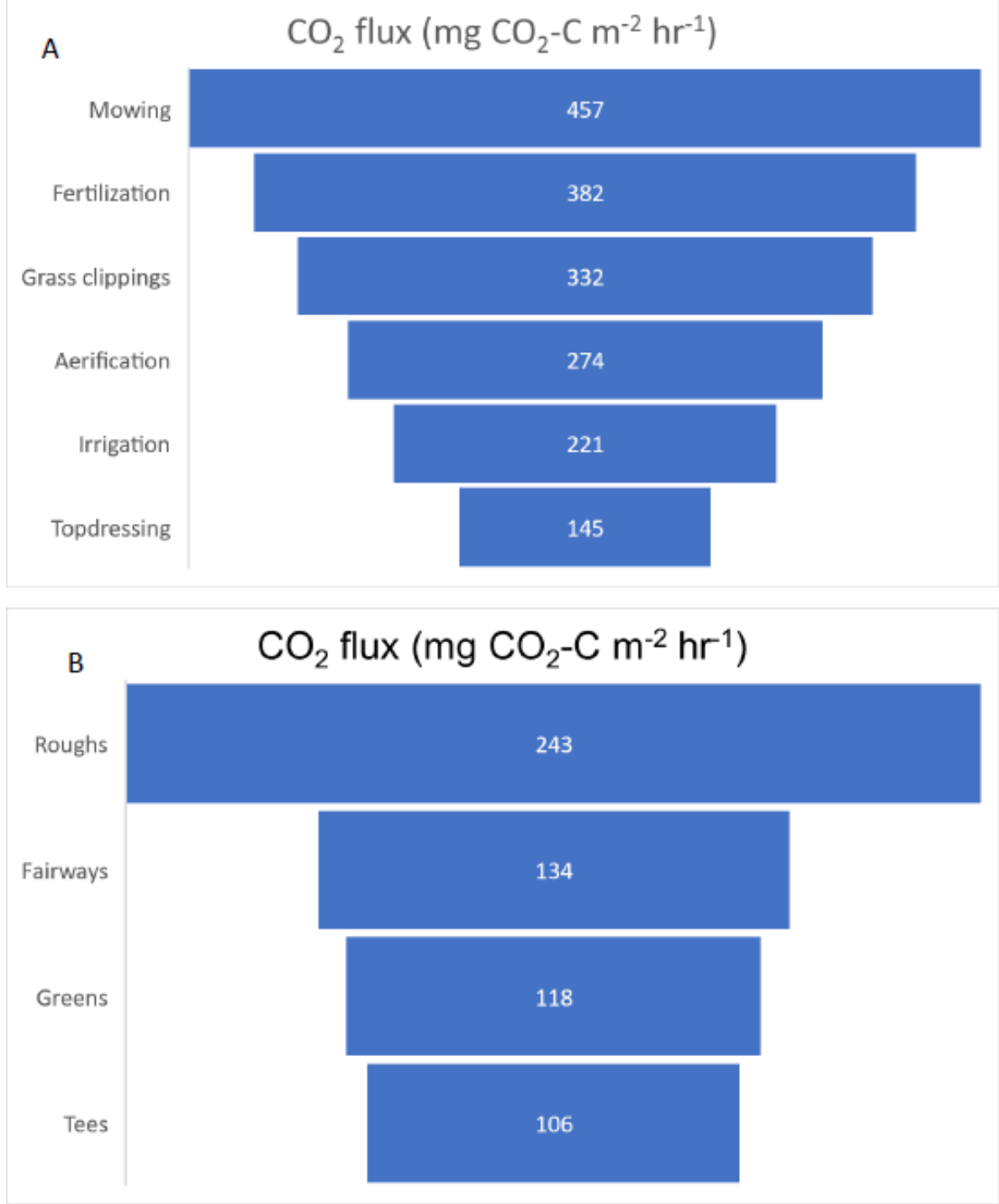

Figure 2 The $\mathrm{CO}_{2}$ flux $\left(\mathrm{t} \mathrm{CO}_{2} \mathrm{C} \mathrm{m}^{-2} \mathrm{~h}^{-1}\right)$ for processes within the golf course $(A)$ and fluxes from turfgrasses across the various playing surfaces $(n=5)(B)$.

\subsection{Simulation (What-If) Analysis}

The production of electricity influences GHG emissions. In this study, electricity was assumed to be generated primarily from natural gas, and the highest increase in GHG emissions was for fairways (Figure 3). The emission of the calculated $\mathrm{CO}_{2}$ was accounted for, while the emission of $\mathrm{N}_{2} \mathrm{O}$ was assumed to be $1.5 \%$ of the $\mathrm{N}$ applied as fertilizer and emitted into the atmosphere. Since the grass clippings were left to decompose, $\mathrm{N}_{2} \mathrm{O}$ emissions from grass clippings were accounted for by the same emission factor. A previous report [24], also within an urban environment, showed that $\mathrm{N}_{2} \mathrm{O}$ emissions based on modeling data can range between 1.05 and $5.3 \mathrm{~kg} \mathrm{ha}^{-1}$ year $^{-1}$ when 5 to $100 \mathrm{~kg}$ of $\mathrm{N}$ fertilizers are applied. The report also highlighted that the decomposition of lawn clippings is a key source of $\mathrm{N}_{2} \mathrm{O}$ emissions. Although no actual readings for $\mathrm{N}_{2} \mathrm{O}$ emissions were obtained, we collected data (unpublished) on the net primary production (NPP) for aboveground biomass, which 
showed significantly higher NPP in the fairways and roughs. Similarly, a strong influence of fairways and roughs on $\mathrm{N}_{2} \mathrm{O}$ emissions was observed in the simulation (Figure 3 ). The uptake of $\mathrm{N}$ was estimated to be $4.5 \%$ of the NPP, according to previous reports on turfgrass in golf courses [17] and within urban boundaries [25]. A 50\% reduction was considered to be the estimate for $\mathrm{N}$ levels in grass clippings for the roughs (2.25\% of NPP) that received no fertilizers.

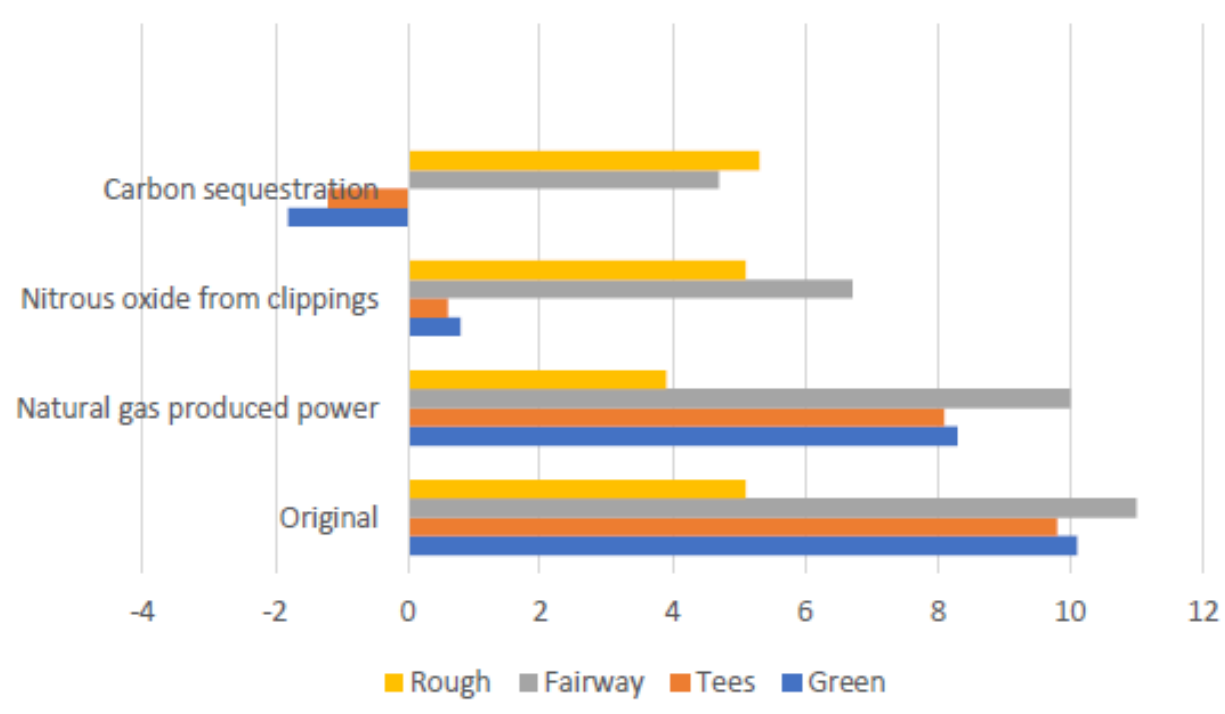

Figure 3 The assumptions applied to $\mathrm{GHG}$ emissions $\left(\mathrm{t} \mathrm{CO}_{2} \mathrm{e} \mathrm{ha}{ }^{-1}\right)$ in a simulation analysis for the golf course for soil carbon sequestration, $\mathrm{N}_{2} \mathrm{O}$ emissions from grass clippings, the power generation from natural gas, and the controlled conditions (original).

Soil $\mathrm{C}$ was assumed to have progressively increased since the development of the course about 30 years ago, and the storage of $\mathrm{C}$ can effectively offset the emissions of GHG from roughs and fairways. Similar to the data on NPP, the data on $C$ (unpublished) for the course indicated that the top $20 \mathrm{~cm}$ of soil in the course contained approximately $98 \mathrm{Mg} \mathrm{C} \mathrm{ha}^{-1}$ in a year. Using this information, we inferred that the land areas covered by the roughs and fairways would be able to sequester an average of $5 \mathrm{Mg} \mathrm{C}$ ha $^{-1}$ year $^{-1}$.

\section{Discussion}

\subsection{Energy Consumption}

Mowing and irrigation were the most widely applied maintenance activities across all playing surfaces in the golf course. Mowing had a high demand for fuel, which caused high energy consumption and GHG emissions. The golf course investigated in this study was situated in a tropical equatorial region, where the climate was warm all year round, and turfgrass growth occurred throughout the year. Thus, frequent mowing was inevitable. Additionally, the course was frequently aerated, which increased energy consumption and GHG emissions.

Irrigation was powered by electricity and thus, contributed to lower energy requirements and lower GHG emissions. The annual energy consumption was the highest for fairways, followed by greens and tees. This might be due to the greater area covered by fairways relative to the other types of landscapes. The consumption of energy for greens was also relatively high, although they 
occupied a very small area in the course. The high consumption of energy was caused by the more frequent fertilization, mowing, aeration, and sand application in greens compared to the frequency of such activities in fairways and roughs. Bartlett and James [14] and Tidåker et al. [10, 17] found similar results for British and Swedish golf courses, respectively. The roughs were the most energyefficient areas, which was due to infrequent mowing and occasional irrigation that was performed, only when the grass was dry. The $\mathrm{CO}_{2}$ flux for the grass in roughs was the highest. The use of fuelpowered machinery for mowing and hollow tining contributed to higher energy consumption and GHG emissions. Hence, to minimize GHG emissions, more fuel-efficient equipment and machinery need to be used.

\subsection{GHG Emissions}

As found by Bartlett and James [14], GHG emissions were primarily due to mowing, fertilization, and the grass clippings that were left on the roughs to degrade. Measurements of $\mathrm{CO}_{2}$ flux from turfgrass suggested that these values were lower than the emissions from maintenance activities. Consistent with previous reports, this study also found significantly higher rates of GHG emissions due to the application of N-rich fertilizers. GHG emissions were the highest in roughs, despite infrequent mowing and the absence of fertilizer application - two maintenance activities with the highest $\mathrm{CO}_{2}$ flux (Figure 2A). This might be due to the decomposition of grass clippings collected across the golf course and left on the roughs to decompose [26]. The data on $\mathrm{CO}_{2}$ flux indicated that mowing contributed the most to GHG emissions, followed by fertilizer application. This shows the need to quickly switch to more energy-efficient machinery, given the high frequency of mowing required on golf courses. The high levels of $\mathrm{CO}_{2}$ flux due to fertilizer application were due to the release of $\mathrm{CO}_{2}$ and $\mathrm{N}_{2} \mathrm{O}$ following the application of $\mathrm{N}$-rich fertilizers [27]. Similarly, the decomposition of grass clippings on fairways and roughs also contributed to the emission of $\mathrm{CO}_{2}$ and $\mathrm{N}_{2} \mathrm{O}$ [28]. This was supported by the simulation analysis that used an $\mathrm{N}_{2} \mathrm{O}$ factor of $1.5 \%$, which had a strong influence on $\mathrm{N}_{2} \mathrm{O}$ emissions in fairways and roughs (Figure 3). The application of $\mathrm{N}$-rich fertilizers, especially in greens and tees, suggested that future studies should measure them directly instead of using estimates. Although irrigation was performed very frequently, it did not contribute much to GHG emissions. Thus, switching to clean electrical options for as many maintenance activities across the golf course as possible is highly recommended. However, the relationship between carbon footprint and electricity is strongly influenced by the source of power. The simulation analysis (Figure 3) suggested that emission levels can change if power generation depends on cleaner sources.

\subsection{Fertilizer Application}

The application of fertilizers has a strong impact on GHG emissions, as shown here and in previous reports $[10,14]$. Thus, further investigation needs to be performed to stop or reduce the application of $\mathrm{N}$-rich fertilizers while maintaining turf performance. The outcomes of such studies can also be applied to sports fields, lawns, and gardens, where fertilizers are also applied. Additionally, if reducing $\mathrm{N}$-rich fertilizers slows down turfgrass development, it might lead to benefits such as reduced frequency of mowing that can, in turn, reduce the energy needs and GHG emissions associated with mowing. 
Soil C sequestration might effectively offset the emissions of GHG from the course. Our annual estimate of $5 \mathrm{Mg} \mathrm{C}$ ha $^{-1}$ year $^{-1}$ from the simulation might be associated with several assumptions due to insufficient information. It is an area that requires further investigation, and the information can help to convert golf courses from $C$ sources to $C$ sinks.

\section{Conclusion}

$\mathrm{CO}_{2}$ flux from turfgrass was generally lower than the emissions from maintenance activities. Mowing was the most energy-intensive activity across greens, tees, and fairways. Hollow tining and irrigation were also energy-demanding processes. The GHGs emitted due to maintenance activities were the highest for roughs, followed by greens, although maintenance activities performed in roughs were substantially lower. This might be due to the grass clippings that were left to degrade on roughs, as found from the $\mathrm{CO}_{2}$ flux data. Further studies need to be conducted to validate this finding, and these studies are suggested to include the eddy covariance flux technique that continuously provides highly accurate quantitative and qualitative data, which can help to determine diurnal and seasonal variations in $\mathrm{CO}_{2}$ exchange [29] across the golf course.

The application of fertilizers contributed significantly to the emission of GHGs. They can also release $\mathrm{N}_{2} \mathrm{O}$ into the atmosphere during production and after application. Since the recycling of grass clippings might be another potential source of $\mathrm{N}_{2} \mathrm{O}$ emission, there is a need to measure $\mathrm{N}_{2} \mathrm{O}$ levels in the future. Based on the findings of this study, the approaches to reduce GHG emissions and maintain turfgrass require the frequency of mowing, aeration, irrigation, and fertilizer application to be reduced considerably within the course. Moreover, the administrators of golf courses should switch to electrical equipment and plant more shrubs and trees for better maintenance. Maintaining a low carbon footprint in golf courses can sometimes be difficult as the expectations of golfers regarding aesthetics have to be considered while addressing environmental concerns.

\section{Acknowledgments}

Special thanks to the technical team and students at the various academic institutions for field work assistance, interviews, surveys, data collection and analysis. Appreciation and thanks to the community at the golf course for openly sharing all the information they had.

\section{Author Contributions}

Both authors make substantial contributions to concept building, acquisition of data, analysis and interpretation of data. Both authors participated in drafting the article and revising it critically for important intellectual information.

\section{Competing Interests}

The authors have declared that no competing interests exist. 


\section{References}

1. Intergovernmental Panel on Climate Change. ARC6 climate change 2021. The physical science basis [Internet]. Genève: Intergovernmental Panel on Climate Change; 2021 [cited 2022 January 3rd]. Available from: https://www.ipcc.ch/report/ar6/wg1/.

2. Selhorst AL, Lal R. Carbon budgeting in golf course soils of Central Ohio. Urban Ecosyst. 2011; 14: 771-781.

3. Selhorst A, Lal R. Net carbon sequestration potential and emissions in home lawn turfgrasses of the United States. Environ Manag. 2013; 51: 198-208.

4. Today. Two golf courses to be phased out by 2024 [Internet]. Singapore: Today; 2014 [cited 2020 February 20th]. Available from: https://www.todayonline.com/singapore/two-golfcourses-be-phased-out-2024.

5. Colding J, Folke C. The role of golf courses in biodiversity conservation and ecosystem management. Ecosystems. 2009; 12: 191-206.

6. McCormick A, Szunyog A. Is the golf industry doing enough to combat climate change [Internet]? Oakland: GreenBiz Group Inc.; 2021 [cited 2021 July 25th]. Available from: https://www.greenbiz.com/article/golf-industry-doing-enough-combat-climate-change.

7. Fuller J. What to know about the surprising impact golf has on global warming [Internet]. Blue \& Green Tomorrow; 2019 [cited 2021 July 27th]. Available from: https://blueandgreentomorrow.com/environment/surprising-impact-golf-has-on-globalwarming/.

8. Groffman PM, Williams CO, Pouyat RV, Band LE, Yesilonis ID. Nitrate leaching and nitrous oxide flux in urban forests and grasslands. J Environ Qual. 2009; 38: 1848-1860.

9. Intergovernmental Panel on Climate Change. Summary for policymakers. Global warming of $1.5^{\circ} \mathrm{C}$. An IPCC special report on the impacts of global warming of $1.5^{\circ} \mathrm{C}$ above pre-industrial levels and related global greenhouse gas emission pathways, in the context of strengthening the global response to the threat of climate change, sustainable development, and efforts to eradicate poverty [Internet]. Genève: Intergovernmental Panel on Climate Change; 2018. Available https://www.ipcc.ch/site/assets/uploads/sites/2/2019/06/SR15 Full Report High Res.pdf.

10. Tidåker $P$, Bergkvist $G$, Bolinder $M$, Eckersten $H$, Johnsson $H$, Kätterer $T$, et al. Estimating the environmental footprint of barley with improved nitrogen uptake efficiency-a Swedish scenario study. Eur J Agro. 2016; 80: 45-54.

11. Townsend-Small A, Czimczik $\mathrm{Cl}$. Carbon sequestration and greenhouse gas emissions in urban turf. Geophys Res Lett. 2010; 37: L02707.

12. Ignatieva $M$, Ahrné $K$, Wissman J, Eriksson $T$, Tidåker $P$, Hedblom $M$, et al. Lawn as a cultural and ecological phenomenon: A conceptual framework for transdisciplinary research. Urban For Urban Gree. 2015; 14: 383-387.

13. Poeplau C, Marstorp H, Thored K, Kätterer T. Effect of grassland cutting frequency on soil carbon storage-a case study on public lawns in three Swedish cities. Soil. 2016; 2: 175-184.

14. Bartlett MD, James IT. A model of greenhouse gas emissions from the management of turf on two golf courses. Sci Total Environ. 2011; 409: 1357-1367.

15. Abraham EM, Huang B, Bonos SA, Meyer WA. Evaluation of drought resistance for Texas bluegrass, Kentucky bluegrass, and their hybrids. Crop Sci. 2004; 44: 1746-1753. 
16. Pons G, Compta M, Berjaga X, Lulli F, Lopez JM. Intelligent system for optimisation in golf course maintenance. In: Frontiers in artificial intelligence and applications: Artificial intelligence research and development. Amsterdam: IOS Press; 2014. pp.67-76.

17. Tidåker $P$, Wesström $T$, Kätterer $T$. Energy use and greenhouse gas emissions from turf management of two Swedish golf courses. Urban For Urban Green. 2017; 21: 80-87.

18. Horn J, Escobedo FJ, Hinkle R, Hostetler M, Timilsina N. The role of composition, invasives, and maintenance emissions on urban forest carbon stocks. Environ Manag. 2015; 55: 431-442.

19. Lerman SB, Contosta AR. Lawn mowing frequency and its effects on biogenic and anthropogenic carbon dioxide emissions. Landsc Urban Plan. 2019; 182: 114-123.

20. U.S. Environmental Protection Agency. Greenhouse Gas reporting Program (GHGRP)-Key facts \& Figures: EPA greenhouse gas data sets. Washington: United States Environmental Protection Agency; 2018. Available from: https://www.epa.gov/ghgreporting/key-facts-and-figures\#one.

21. Intergovernmental Panel on Climate Change. 2019 refinement to the 2006 IPCC guidelines for national greenhouse gas inventories [Internet]. Genève: Intergovernmental Panel on Climate Change; 2019 [cited 2021 July 22th]. Available from: https://www.ipcc.ch/report/2019refinement-to-the-2006-ipcc-guidelines-for-national-greenhouse-gas-inventories/.

22. The Fertilizer Institute. Environment and energy [Internet]. Arlington: The Fertilizer Institute; 2021 [cited 2021 July 18th]. Available from: https://www.tfi.org/our-industry/state-ofindustry/fertilizer-on-the-farm.

23. Farm Carbon Toolkit. Fertilizer production [Internet]. Scilly: Farm Carbon Toolkit; 2021 [cited 2021 July 15th]. Available from: https://www.farmcarbontoolkit.org.uk/toolkit/fertiliserproduction.

24. Law QD, Trappe JM, Braun RC, Patton AJ. Greenhouse gas fluxes from turfgrass systems: Species, growth rate, clipping management, and environmental effects. J Environ Qual. 2021; 50: 547-557.

25. Fissore C, Baker LA, Hobbie SE, King JY, McFadden JP, Nelson KC, et al. Carbon, nitrogen, and phosphorus fluxes in household ecosystems in the Minneapolis-Saint Paul, Minnesota, urban region. Ecol Appl. 2011; 21: 619-639.

26. Gillette KL, Qian Y, Follett RF, Del Grosso S. Nitrous oxide emissions from a golf course fairway and rough after application of different nitrogen fertilizers. J Environ Qual. 2016; 45: 1788-1795.

27. Gu C, Crane II J, Hornberger G, Carrico A. The effects of household management practices on the global warming potential of urban lawns. J Environ Manag. 2015; 151: 233-242.

28. Li X, Hu F, Bowman D, Shi W. Nitrous oxide production in turfgrass systems: Effects of soil properties and grass clipping recycling. Appl Soil Ecol. 2013; 67: 61-69.

29. Pahari R, Leclerc MY, Zhang G, Nahrawi H, Raymer P. Carbon dynamics of a warm season turfgrass using the eddy-covariance technique. Agric Ecosyst Environ. 2018; 251: 11-25. 
Adv Environ Eng Res 2022; 3(1), doi:10.21926/aeer.2201003

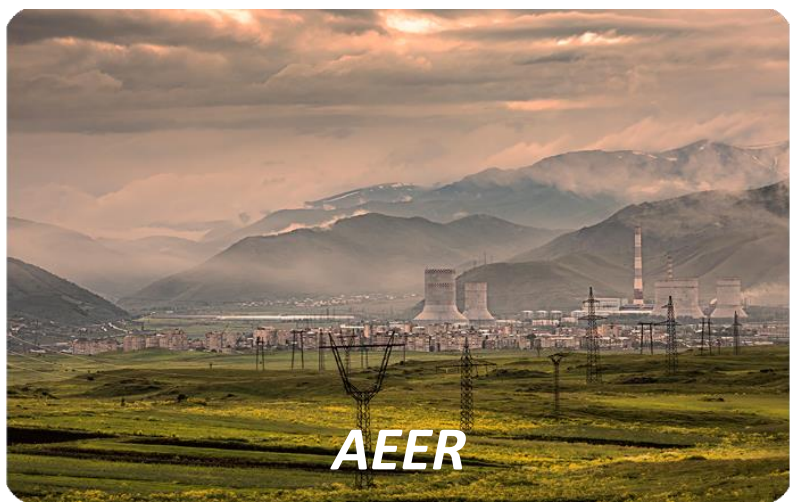

Enjoy $A E E R$ by:

1. Submitting a manuscript

2. Joining in volunteer reviewer bank

3. Joining Editorial Board

4. Guest editing a special issue

For more details, please visit:

http://www.lidsen.com/journals/aeer 